UNIWERSYTET

SZCZECIŃSKI

Zeszyty

Naukowe

n r 858
Wspótczesne

Problemy

Ekonomiczne

$n r 11(2015)$

DOI: 10.18276/wpe.2015.11-07

\title{
Magdalena Sobkowiak-Czarnecka*
}

\section{Umowa o wolnym handlu pomiędzy Unią Europejską a Stanami Zjednoczonymi - szanse i zagrożenia}

Słowa kluczowe: umowa o wolnym handlu, TTIP, wzrost gospodarczy, zagrożenia, szanse

Keywords: TTIP, free trade agreement, growth, chances, threats

\section{Wprowadzenie}

Obecnie negocjowana umowa o wolnym handlu pomiędzy Unią Europejską a Stanami Zjednoczonymi będzie niewątpliwie punktem zwrotnym w relacjach gospodarczych pomiędzy obydwoma partnerami. Samo spojrzenie na dane makroekonomiczne dotyczące tych dwóch gospodarek najlepiej obrazuje skalę tego przedsięwzięcia. Połączony udział Unii Europejskiej i Stanów Zjednoczonych stanowi ponad połowę PKB światowej gospodarki. Warto w tym miejscu dodać, że Stany Zjednoczone są największym partnerem handlowym Unii Europejskiej. Symetrycznie - dla Stanów Zjednoczonych to Unia jest partnerem gospodarczym numer jeden. Negocjacje dotyczące ostatecznego kształtu TTIP (Transatlantic Trade and Investment Partnership) rozpoczęły się w czerwcu 2013 roku. Według danych przedstawianych przez Komisję Europejską zakończyć mają się w tym roku. Samą umowę Komisja Europejska definiuje jako porozumienie, które ma zlikwidować bariery handlowe dla licznych gałęzi gospodarki, tak aby ułatwić zakup i sprzedaż dóbr oraz usług między Unią Europejską a Stanami Zjednoczonymi'.

\footnotetext{
* Magister Magdalena Sobkowiak-Czarnecka jest doktorantką w Kolegium Gospodarki Światowej Szkoły Głównej Handlowej w Warszawie. E-mail: sobkowiakmagda@gmail.com.

1 http://ec.europa.eu/trade/policy/in-focus/ttip/about-ttip/index_pl.htm (14.09.2014).
} 


\section{Geneza powstania umowy o wolnym handlu}

Żeby lepiej zrozumieć, dlaczego Stany Zjednoczone i Unia Europejska zdecydowały się na podjęcie negocjacji prowadzących do stworzenia umowy o wolnym handlu, konieczne jest zapoznanie się ze strukturą wymiany handlowej tych gospodarek na przestrzeni ostatnich kilkunastu lat. Z danych publikowanych przez Eurostat wynika, że w roku 2009 nastąpiło wyraźne załamanie zarówno w eksporcie z Unii do Stanów Zjednoczonych, jak i w imporcie amerykańskich produktów na rynku europejskim. Przyczyn tego zjawiska należy szukać w kryzysie finansowym, a dane makroekonomiczne najlepiej obrazują przeniesienie tego zjawiska ze Stanów Zjednoczonych na stary kontynent. Stąd polityczny pomysł stworzenia umowy o wolnym handlu, która pomogłaby w ponownym pobudzeniu gospodarek, zintensyfikowaniu wymiany handlowej, a zarazem polepszeniu sytuacji makroekonomicznej po obu stronach Atlantyku. Analizując konkluzje z posiedzeń Rady Europejskiej, która dała mandat Komisji na prowadzenie negocjacji z Waszyngtonem, wyraźnie widać, że celem pierwszorzędnym jest pobudzenie wzrostu gospodarczego i wzrost liczby miejsc pracy. W dokumentach Komisji Europejskiej można znaleźć też wzmianki o tym, że negocjowana umowa o wolnym handlu ma stworzyć nowy standard gospodarczy na świecie. W dokumentach amerykańskich pojawia się informacja, że przyjęte założenia mogłyby w przyszłości wpływać między innymi na zasady wymiany handlowej z Chinami - rosnącą potęgą gospodarczą, która przez swój największy udział w amerykańskim imporcie zaczyna dyktować zasady wymiany.

Warto zwrócić uwagę na samą nazwę umowy - Transatlantic Trade and Investment Partnership - co tłumaczyć można jako transatlantyckie partnerstwo w dziedzinie handlu i inwestycji. Określenie ,partnerstwo" ma zagwarantować równość stron w podejmowanych negocjacjach, co dotyczy przede wszystkim standardów ochrony konsumentów. Strony przyjęły zasadę ,równania w górę”, co oznacza przyjmowanie norm, które najlepiej ochronią konsumentów.

Sama umowa o stworzeniu strefy wolnego handlu z definicji powoduje usunięcie barier celnych, jednak w negocjowanym porozumieniu Unia Europejska-Stany Zjednoczone znacznie ważniejsza jest redukcja barier pozataryfowych. Sam poziom obecnych stawek celnych w wymianie pomiędzy Unią a Stanami Zjednoczonymi jest relatywnie niski. W 2011 roku średnia arytmetyczna stawka celna w przywozie z Unii do Stanów Zjednoczonych wyniosła 3,47\%, a w przywozie ze Stanów Zjednoczonych do Unii $4,14 \%{ }^{2}$. Kiedy jednak przyjrzeć się barierom pozataryfowym, to obciążenia z nich wynikające mogą stanowić według danych Komisji Europejskiej nawet $10-20 \%{ }^{3}$. Wynika to

2 Ł. Ambroziak, Analiza wplywu i efektów umowy o SWH UE z USA na gospodarkę Polski, Instytut Badań Rynku, Konsumpcji i Koniunktur, Warszawa 2013, s. 29.

3 http://trade.ec.europa.eu/doclib/docs/2014/may/tradoc_152462.pdf (14.09.2014). 
przede wszystkim z barier biurokratycznych polegających na dodatkowych zezwoleniach na wprowadzenie produktów na nowe rynki, spełnieniu standardów określonych przez rząd partnera handlowego czy zdobyciu certyfikatów. Te kwoty obciążeń, owszem, mogą być minimalizowane przy masowej produkcji stosowanej przez ogromne przedsiębiorstwa, jednak okazują się barierą nie do przejścia dla tak zwanych MSP, czyli małych i średnich przedsiębiorstw. Stąd wprowadzenie TTIP jest przede wszystkim postrzegane jako nadzieja na rozwój dla drobnych przedsiębiorców i otwarcie dla nich dotychczas niedostępnych ze względów ekonomicznych rynków. Raport Amerykańskiej Izby Handlowej w Polsce szacuje nawet, że koszty ponoszone przez producentów na dostosowanie swoich produktów i usług do wymagań regulacyjnych mogą wynieść nawet $60-80 \%$, co wydaje się być dla małych przedsiębiorstw barierą nie do przejścia ${ }^{4}$.

\section{Ocena szans i zagrożeń wynikających z wprowadzenia umowy}

Szukając w literaturze teoretycznych uzasadnień dla powstania powyższego porozumienia, nie sposób nie odnieść się do efektu kreacji handlu. A. Budnikowski w swojej książce Międzynarodowe stosunki gospodarcze zwraca uwagę na to, że „mechanizm efektu kreacji handlu jest swego rodzaju przeciwstawieniem mechanizmu działania cła"s. Warto jednak w tym miejscu nadmienić, że negocjowana obecnie umowa ma dotyczyć nie tylko barier taryfowych, jakimi są cła, ale w dużej mierze zniesienia barier pozataryfowych. Amerykańska Izba Handlowa w Polsce w swoim raporcie TTIP: szanse $i$ wyzwania dla biznesu wskazuje, że Unia Europejska i Stany Zjednoczone mają w planie nie tylko redukcję wysokich stawek celnych. Główne bariery w handlu są związane z regulacjami oraz instrumentami pozataryfowymi. Raport zakłada, że $80 \%$ potencjalnych zysków z TTIP będzie wynikało z możliwego obniżenia kosztów przez przedsiębiorstwa z tytułu zniwelowania barier biurokratycznych i regulacyjnych, a także z liberalizacji handlu w usługach i zamówieniach publicznych ${ }^{6}$.

Nie należy jednak zapominać o efekcie przesunięcia w handlu międzynarodowym. K. Starzyk w publikacji Tradycyjne i nowe kierunki rozwoju handlu międzynarodowego zwraca uwagę na to, że tak jak efekt kreacji handlu w wymiarze stosunków Unia Europejska-Stany Zjednoczone wydaje się być, zważając na ich potencjał ekonomiczny i pozycję w światowym handlu, znaczną korzyścią, to efekt przesunięcia spowodowany przez TTIP może mieć rzeczywisty wpływ na kraje trzecie. Według Starzyka w długim okresie TTIP może wywołać ograniczenie eksportu krajów trzecich, w tym nadwyżko-

\footnotetext{
4 R. Gurbiel, TTIP: szanse i wyzwania dla biznesu, raport Amerykańskiej Izby Handlowej w Polsce, Warszawa 2013, s. 23.

5 A. Budnikowski, Międzynarodowe stosunki gospodarcze, PWE, Warszawa 2006, s. 267.

$6 \quad$ R. Gurbiel, dz. cyt., s. 11.
} 
wych gospodarek wschodzących - tu wymienia przede wszystkim Chiny. W konsekwencji TTIP może wpłynąć na zmniejszenie międzynarodowej nierównowagi płatniczej’

Wyzwanie globalne, jakie stanowi stworzenie nowych miejsc pracy po obu stronach oceanu, opisuje w swoim raporcie Komisja Europejska, szacując, że wymierne korzyści z tytułu TTIP mogą w skali roku wynieść nawet 119 mld euro dla Unii Europejskiej i 95 mld euro dla Stanów Zjednoczonych, co w efekcie miałoby się przełożyć na stworzenie 2,5 mln miejsc pracy. Dodatkowo Komisja przekłada te dane na dodatkowy dochód dla każdej czteroosobowej rodziny, szacując, że wprowadzenie TTIP da średnio 545 euro każdej czteroosobowej rodzinie w Unii Europejskiej i 655 euro rodzinie w Stanach Zjednoczonych ${ }^{8}$.

Większość prognoz opierana jest na raporcie sporządzonym przez brytyjskie Centrum Badań Ekonomicznych (CFER). Wskazuje on także, że po wprowadzeniu w życie umowy eksport z Unii Europejskiej do Stanów Zjednoczonych wzrośnie o 28\%, co odpowiada dodatkowym 187 mld euro w wartości eksportu towarów i usług w Unii. W sumie całkowity eksport Unii Europejskiej wzrośnie o 6\%, a Stanów Zjednoczonych - o 8\% ${ }^{9}$.

Otwarte pozostaje również pytanie dotyczące równomiernego rozłożenia pozytywnych efektów wprowadzenia umowy na poszczególne kraje Unii Europejskiej. Dla celów analizy ważne jest zwrócenie uwagi na rozmieszczenie konkretnych gałęzi przemysłu w Europie. Szacuje się, że największe korzyści może odnieść przemysł motoryzacyjny - przede wszystkim dzięki ujednoliceniu standardów technicznych po obu stronach oceanu. W takim przypadku największe korzyści mogliby odnieść Niemcy, a co za tym idzie - pośrednio Polska. Polskie Ministerstwo Gospodarki szacuje, że szansę na zysk po wprowadzeniu TTIP ma zlokalizowany nad Wisłą sektor lotniczy, telekomunikacyjny oraz produkcji maszyn przemysłowych i urządzeń medycznych ${ }^{10}$.

Jeśliby analizować ewentualne korzyści wynikające z zawarcia umowy przez pryzmat Polski, warto przede wszystkim zwrócić uwagę na otwierającą się szansę dla małych i średnich przedsiębiorstw. Według danych GUS takie firmy generują nad Wisłą blisko 3/4 $\mathrm{PKB}^{11}$, co najlepiej pokazuje skalę potencjalnych możliwości dla rozwoju polskiej gospodarki, gdyby przez zniesienie barier pozataryfowych małe i średnie przedsiębiorstwa mogły pozyskać nowe rynki zbytu. Ważną z polskiej perspektywy kwestią jest wyeliminowanie ograniczeń w handlu źródłami energii. Przede wszystkim Polska

7 S. Wydymus, M. Maciejewski, Tradycyjne i nowe kierunki rozwoju handlu międzynarodowego, CeDeWu, Warszawa 2014.

8 Impact Assessment Report on the Future of EU-US Trade Relations, http://trade.ec.europa.eu/doclib/ docs/2013/march/tradoc_150759.pdf(14.09.2014).

9 www.mg.gov.pl/Wspolpraca+miedzynarodowa/Handel+zagraniczny/TTIP/Publikacje+dotyczace $+\mathrm{TTIP} / 5+$ najwazniejszych+perspektyw+i+nadziei+TTIP/Bezposredni+wp\%C5\%82yw+ekonomiczny (14.09.2014).

10 www.mg.gov.pl/Wspolpraca+miedzynarodowa/Handel+zagraniczny/TTIP (14.09.2014).

11 www.parp.gov.pl/files/74/81/626/18355.pdf (14.09.2014). 
liczy na zniesienie ograniczeń w eksporcie gazu ze Stanów Zjednoczonych. Taki krok pozwoliłby na uniezależnienie od dostaw rosyjskiego surowca, co w obecnej sytuacji geopolitycznej jest dla Warszawy niezwykle ważne. Dodatkowo możliwości pozyskania tańszego surowca mogłoby prowadzić do podwyższenia konkurencyjności polskich przedsiębiorstw poprzez obniżenie kosztów wytworzenia. Analizując poprzednie zawierane przez Stany Zjednoczone umowy o wolnym handlu, można mieć pewność, że wątek handlu surowcami znajdzie się w negocjowanym przez Brukselę i Waszyngton porozumieniu. Kolejnym ważnym aspektem poruszanym już w tym artykule jest możliwość pośredniego zysku osiąganego przez polskie przedsiębiorstw. Zniesienie barier pozwoliłoby na zwiększenie eksportu do Stanów Zjednoczonych wytwarzanych w Niemczech samochodów, a polscy przedsiębiorcy w dużej mierze są producentami części i akcesoriów przesyłanych niemieckim kontrahentom. TTIP miałoby być też szansą na zwiększenie liczby amerykańskich inwestycji bezpośrednich nad Wisłą.

Wiele kontrowersji budzi temat produktów rolnych. Zniesienie barier taryfowych i pozataryfowych wzbudza obawę przed zalaniem europejskiego rynku przez produkty rolne pochodzące ze Stanów Zjednoczonych, co mogłoby osłabić pozycję Polski na europejskim rynku. Dodatkową kwestią jest kształt ostatecznego porozumienia dotyczącego żywności modyfikowanej genetycznie. W Stanach Zjednoczonych obowiązują znacznie bardziej liberalne przepisy w tej materii - producenci nie mają nawet obowiązku informowania o GMO. W Europie te przepisy są znacznie bardziej restrykcyjne. Wynika to przede wszystkim ze sprzeciwu na liberalizację przepisów ze strony takich krajów, jak Polska. W tym przypadku nadzieją może być deklarowana przed Komisją Europejską chęć równania standardów „,w górę”.

Kolejną otwartą dla Polski sprawą jest ewentualność zniesienia wiz w związku z wprowadzeniem umowy o wolnym handlu. Bierze się to z negocjowanych zapisów o swobodnym przepływie osób, na co obecny stan prawny nie pozwala. Cztery kraje należące do Unii Europejskiej - Bułgaria, Rumunia, Cypr i Polska - wciąż są objęte programem wizowym, co taki przepływ uniemożliwia.

Ważnym elementem przy analizie szans i zagrożeń wynikających z wprowadzenia TTIP jest wpływ umowy na całą światową gospodarkę. Komisja Europejska deklaruje, że będzie to jedynie wpływ pozytywny, bo według jej danych spowoduje wzrost PKB w nieobjętych umową krajach o 100 mld euro ${ }^{12}$. Jednak raport przygotowany przez Fundacje Bertelsmanna wskazuje już na nieco inne efekty. Wspomina on między innymi o wymianie handlowej z tak zwanymi krajami BRICS (Brazylia, Rosja, Indie, Chiny i Republika Południowej Afryki). Raport szacuje, że obroty w tej wymianie spadną z punktu widzenia Niemiec o 10\%, a z punktu widzenia Stanów Zjed-

12 http://europa.eu/rapid/press-release_MEMO-13-564_pl.htm (14.09.2014). 
noczonych - nawet o 30\%. Raport wskazuje ponadto, co może dotyczyć także Polski, że handel krajów wschodnioeuropejskich z sąsiednimi gospodarkami zmniejszy się średnio o 5\%, gdyż TTIP zdewaluuje obecne porozumienia gospodarcze. Według tego samego raportu wprowadzenie umowy wywoła spadek bezrobocia w krajach należących do OECD średnio o 0,5 punktu procentowego, jednak nie sprawdzi się to w przypadku każdego państwa, bo na przykład według autorów raportu w Kanadzie może zniknąć nawet 100 tysięcy miejsc pracy ${ }^{13}$. Jak widać na przykładzie przytoczonych powyżej danych, wpływ ekonomiczny porozumienia na globalną gospodarkę może się okazać nie we wszystkich krajach pozytywny, chociaż zapewne ogólnoświatowa średnia najprawdopodobniej będzie dodatnia.

\section{Podsumowanie}

Wejście w życie umowy o wolnym handlu pomiędzy Stanami Zjednoczonymi a Unią Europejską często porównywane jest do szansy na rozwój gospodarczy, jaką Polska otrzymała wraz z wejściem do Unii Europejskiej. Moim zdaniem powtórzenie takiego sukcesu jest niemożliwe, bo na starym kontynencie są państwa, które odniosą znacznie większe korzyści z wejścia w życie porozumienia. Moga to być między innymi Niemcy czy Wielka Brytania. Zagrożeniem wynikającym dla Europy z wprowadzenia umowy może być niewątpliwie pogłębienie różnic gospodarczych pomiędzy państwami UE-28, chociaż niewątpliwie sama umowa jest absolutnie rewolucyjna w historii światowej gospodarki i jeśli tylko uda się ją wprowadzić w życie, będzie pozytywnym impulsem w rozwoju ekonomicznym.

Literatura

About TTIP, http://ec.europa.eu/trade/policy/in-focus/ttip/about-ttip/index_pl.htm.

Ambroziak Ł., Analiza wpływu i efektów umowy o SWH UE z USA na gospodarkę Polski, Instytut Badań Rynku, Konsumpcji i Koniunktur, Warszawa 2013.

Bertelsmann Stiftung Raport, www.bfna.org/sites/default/files/TTIP-GED\%20study\%20 17June\%202013.pdf.

Budnikowski A., Międzynarodowe stosunki gospodarcze, PWE Warszawa 2006.

Gurbiel R., TTIP: szanse i wyzwania dla biznesu, raport Amerykańskiej Izby Handlowej w Polsce, Warszawa 2013.

Impact Assessment Report on the Future of EU-US Trade Relations, http://trade.ec.europa.eu/ doclib/docs/2013/march/tradoc_150759.pdf.

Państwa członkowskie popieraja negocjacje w sprawie inwestycji i handlu pomiędzy UE a USA, http://europa.eu/rapid/press-release_MEMO-13-564_pl.htm.

TTIP in six pages, http://trade.ec.europa.eu/doclib/docs/2014/may/tradoc_152462.pdf.

13 www.bfna.org/sites/default/files/TTIP-GED\%20study\%2017June\%202013.pdf (14.09.2014). 
www.european-council.europa.eu/council-meetings/conclusions.aspx?lang=pl.

www.mg.gov.pl/Wspolpraca+miedzynarodowa/Handel+zagraniczny/TTIP/Publikacje+dotycza ce+TTIP/5+najwazniejszych+perspektyw+i+nadziei+TTIP/Bezposredni+wp\%C5\%82yw+ekonomiczny.

www.parp.gov.pl/files/74/81/626/18355.pdf.

Wydymus S., Maciejewski M., Tradycyjne i nowe kierunki rozwoju handlu międzynarodowego, CeDeWu, Warszawa 2014.

\section{Streszczenie}

Umowa o wolnym handlu pomiędzy Stanami Zjednoczonymi będzie dokumentem o historycznym znaczeniu dla gospodarki światowej. Komisja Europejska szacuje, że jeśli porozumienie wejdzie w życie, może przynieść Unii rocznie dodatkowe 119 mld euro, a Stanom Zjednoczonym - 95 mld euro. Niniejszy artykuł ma na celu zbadanie, w jaki sposób TTIP może pozytywnie wpływać zarówno na gospodarkę światową, jak i polską, ale też jakie zagrożenia niesie za sobą wprowadzenie porozumienia o wolnym handlu pomiędzy partnerami, których połączone gospodarki tworzą ponad połowę światowego PKB.

Transatlantic trade and investment partnership - chances and threats

The Transatlantic Trade and Investment Partnership is set to become a document of historical significance to the global economy. Estimates by the European Commission predict that, once in power, the TTIP will bring annual gains of $95 \mathrm{bn}$ and $119 \mathrm{bn}$ euro to the US and EU economies, respectively. This article aims to evaluate how the TTIP can boost both global and Polish economy, but also to examine potential threats brought about by a free trade agreement between two major players who, between them, account for more than half of the world's GDP.

Translated by Magdalena Sobkowiak-Czarnecka 